\title{
Pojęcie stosowności we współczesnym reportażu radiowym (na wybranych przykładach)
}

Elżbieta Pleszkun-Olejniczakowa 


\title{
Elżbieta Pleszkun-Olejniczakowa
}

\section{Pojęcie stosowności we współczesnym reportażu radiowym (na wybranych przykładach)}

\author{
Granic sztuki nie można przekraczać; \\ można je wylącznie przesuwać
}

(Wladystaw Hasior)

$\mathrm{J}^{\mathrm{s}}$ estem glęboko przekonana, że wiçkszość reportaży radiowych, a z pewnością wszystkie dobre (tylko takie zaś będę tu przywoływać), są sztuką. Zatem owo nieco prowokacyjne motto nie jest, rzecz jasna, przypadkowe.

Dla jasności wywodu będę się posługiwać kilkoma kryteriami, które — moim zdaniem składają się na wspólne pojęcie „stosowności”. W przypadku reportaży radiowych, wedle mego muemania, są to: kryterium e ty c zne (z podtypem bezstronności), kryterium e s t e t y c z n e (z podgrupą wyróżniającą kryterium j ę z y k o w e), i w końcu kryterium, które zwykle wymienia się jako pierwsze, czyli kryterium te m a t y c z n e. Oczywiście kryteria te nie wyczerpują wszelkich możliwości delimitacji: trzeba też uwzględnić i rozważyć ich występowanie w calej historycznej zmienności, pamiętając, iż nawet relatywnic niedhuga historia reportażu radiowego nicjedno w tym zakresie zmienita'. Będę ilustrować te kwestie glów-

\footnotetext{
'O reportażu radiowym pisalam w ubicglorocznych matcrialach Seminarium Reportażu, organizowancgo przez Polskic Radio od lat w Kazimicrzu Dolnym (19-22 pazdzicrnika 2(3)3: s. 33-50). Takze w tym roku ukaże się mój dość obszerny tekst o tym gatunku radiowyn. Początkon reportażu na antenic zaś poświçcilan

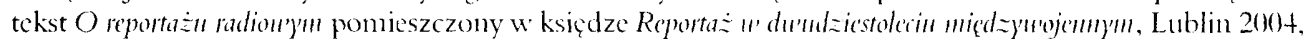
s. 115-123. Należy podkreślić, iz wicle bezcennych informacji o klasyce reportażu radiowego, sięgających aż do lat piçćdzicsiątych, zawicra praca I. Jankowskicj Sztuka reportasul radiourego. |w:] 70) lat Iolskiego Radia, Warszawa 1995, s. 101-111, zaś prawdziwic imponujący rejestr nagrodzonych prac oraz wicle imych nicslychanic ważkich, a niedostçpnych gdzic indzicj wiadoności kryje w sobic inma praca tejże autorki: Reportȧ̇ i dokntment

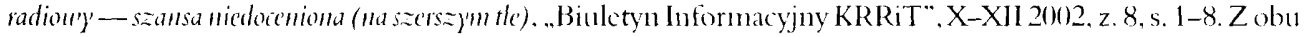


nie na przykladach audycji reportażowych z lat ostatnich (choć nie wyłącznie). Rzetelność naukowa nakazıje mi podziękować w tym miejscu kolejno kierującym Studiem Reportażu i Dokumentu - Janinie Jankowskiej i Irenie Pilatowskiej oraz dyrektor Departamentu Programowego Grażynie Bączkowskiej z Krajowej Rady Radiofonii i Telewizji, dzięki którym dysponowalam stosunkowo obszernym „materiałem audialnym”. Pewną część posiadanych przeze muie materiałów stanowily też po prostu reportaże przeze mnie nagrane, ale nade wszystko audycje zgłoszone na oba ubiegloroczne i tegoroczne, finalizowane w Kazimierzu, konkursy, w których także miałam przyjemność i niewątpliwy zaszczyt być jurorem: Konkursu o Grand Prix. KRRiT i zmagań konkursowych in. Jacka Stwory.

Ze względu na przyjęte ramy wystąpienia ograniczę się do wyliczenia przykładów autorów i tekstów radiowych ${ }^{2}$, bez ich szczegółowej analizy i interpretacji ${ }^{3}$.

Moje rozważania chcę rozpocząć od kryterium - nazwijny to - s t o s ow nośc i te m a t y c z n ej. Czy są jeszcze w ogóle tematy tabu? Czy są granice? A może już wyłącznie s posób ukazania danego tematu podlega kryteriom szeroko rozumianej stosowności wskutek autocenzury twórcy? Ale i działanie owej autocenzury nie musi być bynajmniej jednoznaczne, skoro wybitny twórca malarskiej awangardy francuskiej Georges Braque twierdził, iż uspokaja tylko nauka, sztuka zaś ,jest, by denerwować", a polski malarz, Jan Cybis, niejako wspieral go, sądząc, że - wręcz z definicji - „sztuka obraża”.

Czy kryterium stosowności tematycznej zatem jeszcze istnieje? Jak się zdaje, lista takich tematów drastycznie zmalała. Zważmy, iż jeszcze nie tak dawno byłoby co najmniej niestosowne, a może i niebezpieczne poruszać problem - by wskazać pierwszy dogodny przykład - powrotu dawnych wlaścicieli ziemskich do swych rodowych siedzib, choć skądinąd wykupionych za ich wlasne pieniądze (przywołajny tu choćby interesujący reportaż Romy Leszczyńskiej Dziedziczka Betty'). Tym bardziej owa niewłaściwość byłaby widoczna, gdyby (sympatyczną w dodatku) bohaterką została osoba pochodzenia niemieckiego, jak się to dzieje w bardzo ciekawym reportażu Ireny Linkiewicz Baronou'a ${ }^{\dagger}$. Wszyscy zaś zdajemy sobie

publikacji wiclokrotnie w czasic pisania tego tckstu korzystalan, nic kwitując juz jednak każdorazowo (z myślą o możliwic maksymalnym ograniczeniu liczby przypisów) tego faktu.

: Dalej będę używać okseśleń .. reportaż radiowy” lub .dokunnent radiowy” wymiennie z terminem .,tekst radiowy", przyjmując, iz kazdy tek st me di a ln y jest równoczésnic te k s te m w znaczeniu kulturowym. ${ }^{3}$ Próbą odpowiedzi na ge $n$ e r a l n i c postawionc pytanic o stosowność w reportażu radiowym, ze wskazanicm kilku cech wyraźnic odróżniających dzicú dzisiejszy radia (i pracę radiowców) od stanu i norm sprzec kilku i kilkunastu lat, jest wystąpienic $i$ artykuh mojcj seminarzystki Kingi Klimczak. Przedmiotem jej rozpra. wy magisterskicj są wybrane teksty radiowe Janiny Jankowskicj, stąd szerokie wykorzystanie przez nią w roz. ważaniach rozmów z autorką Polskiego Sicrpinia i jej reportaży.

+ Można tu suuć analogie także z tematyką nicwątpliwic wartą osobnego przedstawienia - określając rzec: najszerzcj: kresowo-patriotyczną. Czasami autorzy kladą akcent na pierwszy czlon określenia, jak np. w re portażu A. Czarkowskicj i A. Pictruczuk Jak ta recka. poświęconym zasaduiczo Czeslawowi Niemenowi w tekścic radiowym I. Pilatowskicj o dwu ksiçżach-Polakach (Polskic slady " Odessic) lub w relacji Jak Bug d K. Nowak - dźwiçkowej wyprawie śladami (jlogera. Bywa ów temat zabarwiony też nic tylko wyraźnic pa triotycznic, ale wręcz ,mitycznie”. jak w glęboko poruszającym reportażu I. Pilatowskicj Saga rodzimma, które go bohaterka. Katarzyna Jarzgunowicz. zyje miçdzy zwaśnionymi rodzinami ojea i matki, niczym między ro dami Montecehich i Capulettich, jak bardzo. bardzo samotna Julia. 
sprawę, iz aby w czasach realnego socjalizmu powstały klasyczne juz dzieła krytykujące PRL, potrze ba było nie lada odwagi w podejściu do obowiązującego wówczas kryterium stosowności tematycznej. By owe teksty radiowe stanowily nie tylko materiał dla historyków, lecz także stały się artystycznymi dzielami sztuki, konieczna była wszakże zarówno odwaga, jak i niemały talent ich twórców. Ta wielka klasyka polskiego reportażu, często nagradzana ${ }^{3}$, wymaga osobnego, wnikliwego, a zatem i obszernego opisania (co dokonuje się częściowo choćby w powstających pod moim kierunkiem pracach magisterskich). Tymczasem ograniczę się do wymienienia kanonicznych dziet tych lat. Są to: Janiny Jankowskiej Polski Sierpien (gdzie tytuł objaśnia już tematykę) i Oszukani (reportaż ukazujący zabójców i okoliczności towarzyszące morderstwu księdza Jerzego Popiełuszki); Jolanty Kulikowskiej i Michała Jagodziniskiego Anatomia strajku (w tym wypadku - wroclawskich kolejarzy); Barbary I liczko i Agaty Eawniczak Kędy sieu' padnie zdrow'y' (o poznańskim Czerwcu 1956); Krystyny Melion Legitymacja partyjna i Radom 1976; Ireny Piłatowskiej Przestanic (o losach Polki, wychowanej w ZSRR, walczącej o rehabilitację swych rodziców - przedwojennych komunistów, straconych w Rosji w latach trzydziestych) czy Jerzego Tuszewskiego o jasnym tytule: Festung Breslan albo liryezma pamiątka po tragiczlly'm mieście nad Odrą.

Od powrotu do pracy w 1989 roku dziennikarzy relegowanych w stanie wojennym po dzień dzisiejszy trwa uzupelnianie „białych plam” historii. Lista jest długa, wymienię więc tylko kilka nazwisk i tytułów. Maria Blimel jest autorką reportażu Nikt nie uidziat (o śmierci chłopca w wypadkach poznańskich); Czesława Borowik - Tu, gdzic jeszcze cisza tru'a (jedynego bodaj tekstu radiowego o obozie zaghady w Krzesimowie kolo Lublina); Maciej Drygas Testamentu (rekonstruującego wydarzenia 1968 roku oraz samospalenie Ryszarda Siwca). Barbara Grębicka zrealizowala reportaże Bitu'a, która zderydou'ata o losach sun'iata (o „cudzie nad Wisłą" 1920 roku) oraz Jacy by/iśmy' - kim stalisim)' się' (próba ukazania, czym w życiu wielu ludzi stał się udział w Powstaniu Warszawskim). Patrycja Gruszczyníska zrelacjonowala polsko-niemiecką wystawę (tytułowe Zbrodnie Wehrmadıtu); Dorota Juchnowska przedstawiła postać więzionego biskupa kieleckiego Czeslawa Kaczmarka: Amu Kaczkowska w reportażu Persona to ja mówiła o zbrodniach Ukraińskiej Powstańczej Armii. Jolanta Krysowata zrealizowała prawdziwie poruszający dokument Osieroceni o nieznanym epizodzie pobytu w latach pięćdziesiątych sierot koreańskich w Polsce, zaś Krystyna Melion - reportaż o Powstaniu Warszawskim: Zu'yczajni, prości, nieogrommi. Zamykając tę bardzo wybiórczą listę, koniecznie należy jeszcze wymienić autorów epickiego reportażu dokumentalnego o tragicznych wyda-

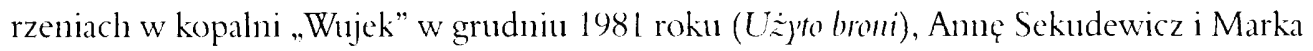
Mierzwiaka.

Mówiliśmy o odwadze notowania „historii na gorąco”. I dziś wszakże trzeba jej nieraz sporo - nie tylko cywilnej, ale i tej, by tak rzec, dostownej, wiążącej się z pokonywaniem wielu trudności, narażaniem zdrowia, a czasem nawet życia. Liczący jedenaście lat „reporter” Tomek

${ }^{5}$ Nic informuję kazdorazowo. czy i jaka nagroda zostal uhonorowany dany reportaż. ponicważ tego rodzaju dokumentacja wydluzalaby tekst zuacznic poza zakieślone rany: 
Puchalski, bohater reportażu Marii Blimel i Wandy Wasilewskiej Zau'ód na czasie, stwierdza z przejęciem: „To nie jest taki bezpieczny zawód (...) Są różne wojny”. S ą ró ż n e w oj n y.

Tematyka reportażu wojennego bodaj nigdy nie była objęta jakimś zwyczajowym zakazem. Jednak tylko autocenzura twórcy decyduje, czy w reportażu tego rodzaju granice kryterium „dobrego smaku”, czyli kryterium es te t y c z n e go (pamiętam oczywiście o jego historycznej względności), ani kryterimu e ty c z n e go nie zostaną przez autora reportażu przekroczone. Przypomnijmy trzy tylko, za to doskonałe, reportaże o wojnie na Balkanach: Cezarego Galka Requiem dla Bośni, Pilatowskiej Kosou'o z daleka, i dokument Jankowskiej oraz Pilatowskiej IV imię czego? Wpierw wszelako podkreślmy, że wszystkie trzy wymienione teksty radiowe glęboko poruszają, a dotyczą losu różnych narodów bylej Jugoslawii. I nie pozostawiają nas w przekonaniu, iż jakiś jeden naród jest szczególnie winny, inne zaś składają się tylko z ofiar. Mimo to, a może wlaśnie dlatego, długo rozmyślamy o tych dziełach. Pozostają one w naszej pamięci, ale nie mamy wątpliwości, że nie tylko nie poniosły tu uszczerbku kryteria estetyczne i etyczne, ale także nie ucierpiała chyba specjalnie wolność ich twórców".

Niełatwo zapewne, prezentując konflikt, rozstrzygać o obecności czy wręcz niezbędności kryterium obiektywizmu, bezstronności. i jeśli taka właśnie jest decyzja twórcy, wytrwać przy owym kryterium. Wyobrażan sobie, że robiąc reportaż, powiedzmy o morderstwie, trudno wysłuchać nie tylko ofiar, ale i sprawcy; podobnie jak uważając homoseksualizm za podlegającą leczeniu (i wyleczeniu) chorobę. uczciwie przedstawiać racje tych, którzy ani myślą się leczyć, a przeciwnie, chcą głośno mówić o swych odniennych od większości preferencjach seksualnych. Przykłady można by mnożyć. Wyrażę więc tylko mój pogląd, iż — choć z pewnością istnieją także inne reportaże w pełni mogące sprostać kryterium obiektywizmu - dla mnie przykladem wlaściwie idealnym w tej mierze jest wspomniany tekst radiowy $W$ imięczego? Być może pomógl tu fakt, że reportaż ma dwie autorki? Może jego budowa ramowa ${ }^{7}$ ? Nie sądzę jednak, by były to okoliczności decydujące. Racje - i nade wszystko krzywdy - tak Chorwatów, jak Serbów, są doskonale wyważone, co w niczym, podkreślmy, nie pomniejsza ogromnego wrażenia, jakie ten reportaż wywiera na słuchaczu.

Wojna to także terroryzm, potępiany wszak ex defintitone; jednak i tu bywa potrzebna bezstronność. Piłatowska pojechała do Moskwy tuz po tragedii w Teatrze na Dubrowce w roku

\footnotetext{
"O ile mogę wnosić z rozmów i korespondencji. nic tylko wymicrne nagrody, ale i reakcja odbiorców, świadomość, jak ważny jest dla nich rezultat pracy reportera, znaczy nicraz tyle co najcennicjsze dyplomy i premie Dokumentowanic wickkich i ważnych wydarzeń jest (lub choćby: bywa) nagrodą samą w sobic. Pamiętan: rozmowę z J. Jankowską o odbiorze jej Polskiego Sierpuia przez Amerykanów, dla których rzecz — zdawałoby siç - jest prawie weale nicznana. Nicdawno (we wrześnin 2(0)+ r.). przy okazji nagrody odebranej przez niz w Moldawii, autorka napisala do mnic: ,nagroda (...) to książczzka lrena - zmaczy poḱój (...) To rzecz i o mnie i - co ważnicjsza - o tym, jaki ślad w świadomości i codzicmności tantcjszych radiowców pozostawia moj، pojawienie sic w Moldawii. Nie spodzicwalam siç. ze az tak wiclkie ma to znaczenic dla niclı”.

O specyficznych cechach konstrukcyjnych reportazu radiowego pisali miçdzy innymi: J. Mayen (Radio a lite.

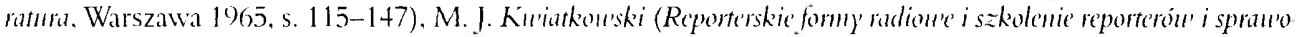

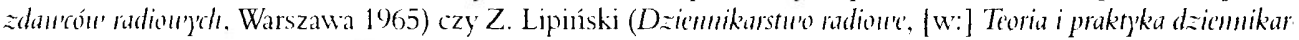
stu'a. Warszawa 1964. s. 180-194). Najwyraźnicj jednak uwagę na analogie i zbieżności między stuchowiskien a reportażem radiowym zwrócil wybitny znawca takze tego pierwszego gatunku. M. Kaziów (Art'styezmy repor

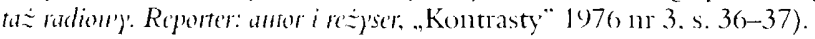


2002. W reportażu Gtosy' i miejsce ma cisze słuchany jednak nie tylko przedstawicieli rodzin ofiar i nie tylko glosów rozsądnych Rosjan (do których reporterowi waale nie było latwo dotrzeć) $)^{8}$. Moskwianie - także ci „z ulicy” - wygłaszają częściej sądy, po wyshuchaniu których maleje nasze współczucie i zmienia się punkt widzenia. Oto bowiem próbki ich wypowiedzi: "Jestem dumna z naszych wojsk; wszystko zrobili, co trzeba”; "Stalin miał rację — trzeba Czeczenów na Kaukaz”; „Zrównać Czeczenię z ziemią” etc. Spojrzenie na relacje krzywd i wzajemnych rachunków przestają już być dla kogokolwick, kto wysłuchał tego reportażu, jednoznaczne, proste i latwe.

Bywajajednak czasami, po wichn, wielu latach, osobliwie cieple i dobre skutki wojen. Polska dziennikarka jako nułoda dziewczyna poznaje Afgańczyków z maleńkiej podgórskiej wioski i przyczynia się między innymi do uratowania życia pewnego miejscowego chtopca. Po latach odnajduje ową wieś, owego - dorosłego juz - Afgańczyka, ale nade wszystko odnajduje czekającą tam na nią ich wdzięczność i przyjaźń. Zdola nawet wręczyć in - względnie malą dla nas, kolosalną dla nich — sumę pieniędzy, która pozwoli im odnowić (a praktycznie: zbudować) dom i uratuje od „emigracji” do glodującego Kabulu. Ta zaiste magiczna w swym klimacie opowieść to reportaż Krzysztofa Wyrzykowskiego Historia trzed pierścieni.

Jak się zdaje, właśnie szczególnie w zakresie kryterium tematycznego i - szeroko pojętego - estetycznego, choć nieraz lączą się one integralnie także z kryteriun etycznym, stosunkowo latwo i wyraźnie można prześled zić różnice. Jedna z dziewcząt zabierających głos w reportażu Elementarz Mariusza Kamińskiego stwierdza wręcz: „Nas trzeba zszokować, bo wtedy to do nas dociera". I tak, o ile - jak przypuszczam - mógl jeszcze przed pól wiekiem niejednego stuchacza zaskoczyć, a nawet zaszokować, stynny „reportaż z narodzin”, czyli Oczekiuranie Witolda Zadrowskiego i Jerzego Janickiego, gdzie inżynier radiowy I Ienryk Siejka dokonal niemal technicznego cudu: quasi-transmisji z narodzin niemowląt i rozmów „na gorąco” młodych mam z ojcami, dziś możemy wysłuchać na przyklad reportażu Grzegorza Fafinískiego o matkach, które... porzucają swe dzieci tuż po urodzeniu (Jak mi prędko bije tu'oje serce').

Wyznaję, że nie dane mi było nigdy wysłuchać pierwszego polskiego międzynarodowego sukcesu w dziedzinie reportażu, czyli Śmierci słonia Zadrowskiego, ale sądzę, że strzal kończący życie wymienionego w tytule wspaniałego zwierzęcia wzbudziłby we mnie żywy sprzeciw. Opowieść otwierająca reportaż Marty Miller i Alicji Grembowicz Selau'i, jak to się món'i, mimo całej metaforyzacji sensu, wystawila mnie na najwiçkszą próbę (w tym i tak skądinąd poruszającym tekście radiowym); a jest to opowieść o eksperymencie tylko (?) na kocie. Cóż mówić o gehennie zwierząt w fermach przemysłowego tuczu (Meatrix Magdy Skawińskiej) czy o sposobach „połowu” ryb, stosowanych przez kłusowników (Dzicri gnieu'u, dzien ostatni - Piłatowskiej), o gehennie koni, transportowanych w strasznych warunkach ma rzeź do Włoch lub - generalnie - o bardzo, moim zdaniem, ważnych problemach ekologicznych

\footnotetext{
${ }^{8}$ W roku 2003 do konkursu o Grand Prix zgłoszono także bardzo ., cicply” tckst radiowy reporterki z rozglośni krakowskicj. E. Szkurłat-Adamskicj. Kochmo Nataszo, oparty na listach polskich dzieci do dziewczynki. która stracila matkç wlaśnic w Teatrze na Dubrowce.
} 
(np. Droga przez osiedle IJanny Bogoryja-Zakrzewskiej i Emesta Zozunia), poruszanych w obecnym wlaśnie na antenie cyklı Zielona Alternaty'u'a? Tak więc, jak nietrudno spostrzec, s posób ukazywania tematów do pewnego stopnia zbliżonych, s i ł a uż y y ch bodźców na przestrzeni kilkıdziesięciu lat zmieniła w sposób znaczący rozumienie kryterium stosowności estetycznej i etyczncj.

Skoro mowa zaś o kryterium estetycznym, warto może, choćby najkrócej, wspomnieć o jego „podtypie”: kryterium językowym. Rażą mnie określenia obsceniczne. Wszelako, jeśli reporter chce ukazać środowisko, które ma swój określony język, na przykład hip-hopowców (jak czynią choćby autorki reportażu Peja-B Blimel i Wasilewska), powinien by dokonać swoistego dzieła translatorskiego. Zatem albo trzeba ustalić, że pewnych środowisk i osób wcale się nie prezentuje, lub - obawian się - trzeba bez protestów słuchać, jak Ryszard Andrzejewski, czyli gwiazda hip-hopu Peja, żali się, że „namnożylo się tych wywiadów”, używając nieustannie, jak to wytwornie określił niegdyś Kazimierz Nitsch, , nazwy nierządnicy w charakterze znaku przestankowego". Zaghuszanie ani wycinanie pojedynczych słów nie jest akurat, wedle mego zdania, rozwiązaniem wlaśnie e s te t y c z n i e szczęśliwym, bowiem zafałszowuje realistyczny - w myśl założeń poetyki przyjętej przez twórców - obraz. Internetou'a sprau'iedliu'ośc Lucjana Muszyńskiego zwraca się z kolei ku wymienionemu w tytule medium i podejmuje problem obelg w Internecie; imna rzecz, iż wystarczy przeczytać część internetowych inwektyw piosenkarki Edyty Górniak pod adresem dziennikarzy, by uznać młodzieńca z reportażu Muszyńskiego za wyjątkowo powściagliwego.

Z innym zagadnieniem mamy do czynienia, gdy język danej osoby jest niejako znakiem jej tożsamości, jak na przykład szczególna polszczyzna cudzoziemca Svena Matzke ze świetnego tekstu radiowego Galka Znajdzicsz mmie "l' szeptad trau' czy specyficzna polszczyzna przynależącego do quasi-cyganerii bohatera Strażnika bajek tegoż autora, gdzie kolokwializmy w rodzaju: ,i chodı”, ,z każdą żoną namawiałem się do śmierci”, mieszają się z wulgaryzmami: .,pomalowatem sobie mordę”, ,rozpieprzyliśmy niedzielę”, „gołymi dupami”, „gówno” etc. Może bez tylu wulgaryzmów, za to bodaj barwniej zlorzeczy Unii Europejskiej jeden z bohaterów reportażu Agnieszki Czarkowskiej Niech ta Unia wie; no bo „Unia to jest takie gniazdo (...) To bestia (...) Może prawnukom będzie lepiej; a my bedziem jak te dzikie świnie, jak te dziki...". Wszelaka cenzura wydaje mi się jednak w tyın wypadku nie tylko nieskuteczna, ale wręcz nienożliwa bez dość jawnego pogwatcenia integralnej calości dzieła, skoro i temat, i postaci, i ich język składają się na ś w i a t p r z ed s t a w i o n y każdego tekstu, a więc i tekstu radiowego. Niemniej przyznaję, że rodzi się istotne pytanie: czy autor reportażu, pozwalając swoim bohaterom, niekiedy sympatycznyın, mówić swobodnie językiem pelnym wulgaryzmów, nie przyczynia się do tworzenia mody językowej, gdzie m o c n i ludzie mówią m o c n y $m$ językiem? (Przypomnijmy choćby oba filmy Władyshawa Pasikowskiego: Psy' i Psy 2).

Pozostał mijeszcze pewien istotny, jak sądzę, , aneks" odnoszący się tak do kryterium estetycznego, jak i etycznego. Pracującej wśród prostytutek, stykającej się ze światem przemocy, lęku i niegodziwości siostrze Annie, z cechującego się szczególną wrażliwością reportażu Sekudewicz Rozmou'y' z siostrą Amma, zdarzają się błędy gramatyczne, co drugie zdanie kończy 
slówkiem „nie?” - ale jednoczéśnie na stwierdzenie autorki dzieła, że jest dıżo zla na świecie, odpowiada: „Nie generalizujmy. Zlo jest bardziej krzykliwe, ale jest też dużo miłości i piękna". Kryterium etyczne spełnione przez to dzieło tak dalece przeważa nad ewentualnymi niedomogami językowymi bohaterki (gdyby komuś przeszkadzaly), iż rzecz nabiera innej wagi i hierarchii.

Jeszcze innego typu opozycja pojawila się w mojej percepcji, gdy shuchałam (jako juror w roku 20(13) reportazu Malgorzaty Sawickiej Kamienic i mou'a. To juz e s te t y c z n i e bylo trudne; mówily - czy raczej: wydawaly porażające dźwięki osoby po operacji krtani. Wszakze e ty c z n e przesłanie tego dzieła było tak ważkie, iz - moim zdaniem - cel w pelni uświęcil, niełatwe chwilami dla słuchacza, środki.

W jakimś sensie wizerunkiem wspólczesnej zhomogenizowanej kultury popularnej może być reportaż Katarzyny Michalak i Agnieszki Czyżewskiej Nou'e szaty'biskupa. Autorki, doskonale posługując się montażen, osiągają bardzo sugestywny obraz oparty na konstrukcji whaściwej dla antytezy: z jednej strony św. Mikołaj traktowany jest z calą powaga jako jeden z glównych świętych czczonych w prawosławiu", z drugicj św. Mikołaj to po prostu ikona kultury masowej - nienajstaranniej przebrany w udawane szaty biskupa osobnik, rozdający tłoczącemu się tłumowi matek i dzieci prezenty za talony (.jest tylko sto paczek”) plus ,zdjęcie z Mikolajem - gratis". Taki jest ów Mikolaj — kulturowy archetyp, bo przecież już n i e święty - skreślony zresztą nawet niedawno z tej listy przez Kościól katolicki. Ale „świętych nie wolno zaczepiać; nijakiej wiary" - mówi prosta, szczerze wierząca, kobieta z terenów obecnej Ukrainy, która, odwiedzając rodzinę w Polsce, zabiera zawsze d la s w o ic h wodę ze świętego źródełka, bijącego koło cerkwi (...od tej pory nogi mi nie opuchają...”).

Św. Mikolaj - wedle jednego z dziecięcych interlokutorów reporterki - „to jest taka postać, która kiedyś istniala (...). Święty Mikolaj ulotki rozdaje, komórki”. Także język listów z prośbami o prezenty często, szczególnie u dzieci rodziców najbogatszych (jak należy wnosić z ich życzeń), daleki jest od szacunku okazywanego osobom niepospolitym. Owszem, jest i wstrząsające wyznanie: „będę się cieszyć nawet z olówka”, ale przeważają prośby o laptop, stale lącza internetowe lub co najmmicj o lalkę Barbie i plyty CD. Szczerość niektórych listów oraz ich słownictwo są szczególnie wymowne: ... . byłem niegrzeczny, ale [i tak chcę] Robokopa” lub: „Sie masz. Przynieś mi telefon Nokia z aparatem cyfrowym”. To bardzo daleko, chyba już zbyt daleko, by droga byla do przebycia - od owego Santa Clansa, który , może i tańcować", do dawnych oczekiwań związanych ze wszystkimi świętami, szczególnie jednak rzecz jasna — z Bożym Narodzeniem: „.. . bo mama kupi nową sukienkę, pójdzie się do cerkwi ... [pop] da krzyżyka albo obrazek, to tak się potem szło, że aż się ziemi nie tykało”. Cóz jak pisal już prawie cztery wieki temu angielski filozof Thomas I Iobbes: „ludzie odwołıją się

\footnotetext{
"Różne oblicza religii: jej wyznawców, wrogów. przedstawicicli instytucji Kościola. zarówno katolickiego,jak iCerkwi prawoslawnej (szczególnic obecnej na wschodnich obrzeżach Polski). stanowić mogąa także pasjontujący temat rozważań; okazją do nich mogą być dwa doskonate reportaże J. Smyka, których omówienic planuję: Suriętego Gabriela śmieró dla ¿̇ycia (opowiadającego o losach wspólezesnego świętego) oraz Postuga oja Mirona (reportaż prezentujący municha, potcm hicrarchę, Cerkwi prawoslawnej).
} 
od zwyczaju do rozumu i od rozumu do zwyczaju, zależnie od tego, co im jest wygodne, i odstępują od zwyczaju, gdy tylko wymaga tego ich interes".

1)ziennikarstwo śledcze święci w prasie prawdziwe tryumfy; udział w parlamentarnych komisjach śledczych - których transmitowane obrady są oglądane powszechnie niczym najlepsze seriale telewizyjne - pozwalają ich bohaterom stać się gwiazdami zarówno politycznymi, jak i medialnymi. Jak latwo zatracić tu poczucie dobrego smaku, zwykły rozsądek, rozwagę i roztropność, byle sprostać hasłu "Wszystko na sprzedaz”, widać doskonale. Dziennikarze radia publicznego znów stanowią najwyższej próby wyjątek. Krytykują (i krytykowali, gdy było to daleko trudniejsze), ale nie gwałcąc - przynajmniej w reportażach radiowych, które chcę teraz wymienić - ani kryterium stosowności estetycznej, ani etycznej. Tak oto skrajnie niebezpieczne, stale grożące życiu warunki pracy w gónnictwie Anna Sekudewicz i Anna Dudzińska ukazaly w reportażu Zto czai sif' ma dole $e^{(1)}$. W dziele Jankowskiej Pon'ódź u'szystkich Polakóu krytyka autorki reportażu objęła: niewymienionego wprawdzie z nazwiska, ale aż nadto „czytelnego” premiera Wlodzimierza Cimoszewicza i - generalnie - postawę całego ówczesnego aparatu władzy wobec klęski żywiołowej z roku 1997. Zabawnie, ale wcale nie mniej celnie - niczym obrazek ze szczytu epoki gierkowskiej - prezentują przygotowania do króciuteńkiej wizyty obecnego prezydenta Aleksandra Kwaśniewskiego Agnieszka Czarkowska i Alicja Pietruczuk w reportażu o tytule bogatym w skojarzenia: Cały u'asz,

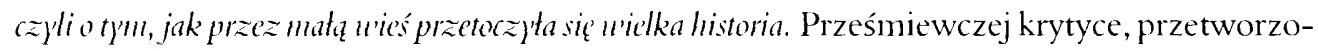
nej niemal w groteskę, mogą też podlegać mechanizmy demokracji, co potwierdzają choćby dwa, naprawdę zabawne, teksty radiowe: Eweliny Karpacz Reasumpcja, czyli pouttórka z glosou'ania i Magdy Skawińskicj oraz Konrada Dulkowskiego Partie listy piszq.

Znane mi są też dość liczne, dobre i bardzo dobre, reportaże prezentujące nędzę, bezrobocie czy rozpaczliwe poszukiwanie pracy, by wymienić tylko: Beaty Cichoń Czarna pranda; Czarkowskiej Elcmentar Mateusza; I Ienryka Dedo i Waldemara Kasperczaka Mieszkancy bunk'ra; Dudzińskiej Bez placy, bez pracy czy Renaty Redy Pisk Ślimaka. Są teksty radiowe wskazujące na sytuację młodzieży żyjącej w takich warunkach (np. Agnieszki Trofmiuk i Andrzeja Bajguza Blok jest moim domem), rodzenie się dzielnic-wylęgarni zła (Malgorzaty Furgi i Anny Kolmer Manhattan - Brookly'n), gdzie coraz częstszym zjawiskiem jest alkoholizm lub narkomania (Miller i Grembowicz Selaui, jak to się móui), aż po całkowitą bezdomność (Troszka smieszno, troszka straszno Beaty Zamlewskicj-Paługi), gdy jedyną dostępną pracą staje się prostytucja (Krótki sezon na jugody' Linkiewicz).

Można wymienić jednak i takie reportaże, które niosą promień nadziei, a czasem nawet mówią o zwycięstwie przy wychodzeniu z bezrobocia, alkoholizmu i narkomanii, bezdomności, by wspomnieć: Nareszcie razem Bogoryja-Zakrzewskiej, Bunkior Dedo i Kasperczaka"

\footnotetext{
"Ten reportaz. w nieco tylko zmienionym ksztalcic i upatrzony obecnic tytukem Cona pracy. zyskal we wrze. śniu bieżacego roku (sic!) glówną nagrodę najstarszego radiowo-telewizyjnego festiwalu Prix Irulia. To wielk sukecs polskiego reportażu.

1: Interesującą i niewątpliwic bardzo cemmą spolecznic akcję prowadzi wśród mlodzjeży gimmazjów i liceóv fundacja „Glos Evangelii”. gdzie swymi doświadezenianui z młodýni dziclą siç ci, którym udalo siç wygra
} 
Retrospekcję Darii Dyktasińskiej, Braci Ediego Kamili Kowalskiej, Pocing do Larszan') Leszczyńskiej, Kolędnicy' z pośredniaka Michalak czy Zobacz czlouricka Ewy Szkurlat-Adamskiej.

Pracy szukają bezrobotni (a często i bezradni) także za granica - przykladowo Polacy w Holandii (w reportażu Eukasza Euczkiewicza W poszukim'anim szklanyeh domón') - lecz także sąsiedzi zza wschodniej granicy, na przykład Ukraińcy, u nas, ale i w Niemczech; wracając - nie zawsze szczęśliwie - przez Polskę do domu (jak w niestychanie poruszającym reportażu Sawickiej Historia przydro ̇nego krzyza). Próbują też żyć w Polsce, niestety lącząc czasem studiowanie z prostytucją czy kontaktami ze światem gangsterskim, o czym mówi hardzo dobry i wcale niejednoznaczny ani latwy w ocenach reportaż Roberta Potockiego Piętno.

Niewątpliwie znakomitą miarą kryteriun etycznego byłoby prześledzenie sposobu, w jaki autor reportażu mierzy się z tematyką śmierci - własnej, zbliżającej się, coraz bardziej osaczającej ofiarę, lub śmierci najbliższych, ale zawsze ś m i e r c i, a więc tego na swój sposób tematu tabu wspólczesnej kultury masowej. Można by tu użyć jako przykładów dzieł radiowych wręcz znakomitych i wielu dobrych, by wymienić tylko - alfabetycznie - choćby następujących autorów i audycje: Galka I stat się and (ale nade wszystko tegoż Znajdziesz mmie u'szcptach trau'); Agnieszki Kamińskiej Byłam ból('m; Malgorzaty Nabel Śmiéréi dzieu'czyna; oba świetnie reportaże Sekudewicz: Adopcja na w'ieczność oraz Wdou'a, czy Rozman'iatam z Nią Żanety Walentyı. Niewątpliwie znaleźć tu się też powinno Siedem dni nadzici Jankowskiej: wstrząsający tekst radiowy o bezdomności, narkomanii, nadziei i... śmierci.

Wszystko to juz jednak zadania na kolejue Naukowe Konferencje. 